\title{
How Implicit Self-Theorist Moderate the Influence of Doctors Communication Skill on Patient Satisfaction: A Case Study in Hospital Industry in Indonesia
}

\author{
Fiktorius Kuludong ${ }^{1}$, Tantri Yanuar Rahmat Syah ${ }^{2}$ \\ Magister Management Esa Unggul University Jakarta
}

\begin{abstract}
An increase the number of visits patients seeking a treatment are thing that need to be concerned to improve hospital revenue. The hospital should be able to create patient satisfaction by improving its service quality. One of the things that are part of service quality is doctors' communication skill on patients. A good communication skill of the doctors will create patient satisfaction. It has been proven in previous researches that said patients showed significantly increase satisfaction to individual consultations, with the greatest increase in satisfaction on doctor communication skills. However, not all patients have the same reaction to communication style of the doctors. So far, there is no researches that includes about doctor communication skills that influenced by the nature of the individual itself, Hence in this research, the researcher wants to include the influence of individual nature on communication skills and patient satisfaction, in which implicit self-theorist will act as moderate variable between the communication skills on patient satisfaction that was not found in previous researches. This study is conducted to 120 respondents of men and women aged 18-70 years who seek outpatient treatment at a hospital in South Jakarta, Indonesia by using a questionnaire. Data analysis method used in this study is General Linear Model (GLM) method. The results of this research is found that the doctor communication skills improve patient satisfaction, especially for a group of individual entity, a group of patients who have a perception of high communication skills have greater satisfaction than the group of patients with the perception of low communication skills and specifically to the group of patients with the perception of low communication skills, the individual incremental group are more satisfied than the individual entity group. This research found that implicit self-theorist moderate communication skills on patient' satisfaction.
\end{abstract}

Keywords: communication skills, implicit self-theorist, patient satisfaction, general linear model

\section{Introduction}

Patient satisfaction is an asset in hospital industry, because satisfied patients will continue to use the services of their choice. However, dissatisfied patient will tell two times more powerful to others about their bad experience (Wahyuni, et al., 2013). One of the factors that affect patient satisfaction in hospital is doctor communication skill. A good communication on the right way of delivery will provide or entail a feeling of acceptance, appreciated, understood and well served, so it will have an impact on increasing the patient satisfaction. Many doctors are judged providing in a hurry services to patients, did not want to listen to patient complaints, and limiting the treatment time of patients with the presumption to earn more income. A constraint that happens is when the doctor already given an explanation, but the patient lack comprehension, so it needs to communicate in a better way. Good communication between doctor and patient need to be supported by a good doctor communication skill in establishing communication with the patient or the patient's family.

Patients who are not satisfied with the hospital considers its services are inadequate, has incomplete facility, perceived the doctors communicate less to the patients as well as the information flow between hospitals and patients that is not smooth and underestimated, especially by upper middle economy patients. This inadequate service is the reason for patients preferring to seek medical treatment abroad. Indonesia's population is estimated at around 300.000 people look for medical treatment abroad every year (Kompas, 2010). In order to create patient satisfaction, the hospital had to manage a system to obtain more patients and the ability to retain patients. However, improvement efforts or perfection of satisfaction can be done with various strategies by hospitals in order to grab customers. Efforts to improve patient satisfaction, hospitals function must be developed continually and as a healthcare institution which organizes complete personal health services, encompassing health care promotion, preventive, curative and rehabilitative, by providing inpatient, outpatient, and emergency services (Law No. 44 of 2009). Hospital should be integrated into the health system in which it is located; its function is as a resource center for the improvement of public health in the region (WHO Hospital Advisory Group Meeting, 1994).

Trumble, et al. (2006) said that patient satisfaction increased with doctor communication skills after communication training, communication skills training intervention succeeded in improving patient satisfaction even increased patient satisfaction in all major areas of healthcare, including fields that are often complained by 
the patient. Patients who had been treated by a doctor who has good communication skills can improve the health indices and the recovery level. An effective communication between doctors and patients give an impact on better healthcare, comfort, patient satisfaction, and decrease the risk of malpractice, as well as conflict or dispute between doctors and patients (Davis and Fallowfield, 1994; Greenfield, et al., 1985; Ong, et al., 1995). However, doctor communication in a form of too complicated explanation is not necessarily will be liked by all patients. Some patients just only want a brief explanation, because the rest is handed over to the science of the doctor. Therefore, a doctor needs know the individual nature of the patient, whether the patient nature is an entity or incremental (implicit self-theorist). Shah (2014) said that individual with incremental tendency, when given the high participation facility will provide a better rational response quality compared to individual with an entity tendency. Whereas on low participation situation, individual with an entity tendency give a better relational quality response compared to incremental tendency.

Previous researches on doctor communication skills to patient satisfaction has been conducted, however, so far there is no research that investigate doctor communication skills which outcome influenced by the individual nature, hence in this research, researcher wanted to include the influence of individual nature toward communication skills and patient satisfaction, so researcher includes implicit self-theorist as a moderating variable between the influence doctor communication skills on patient satisfaction that did not exist in previous research.

\section{Communication Skill}

\section{Literature Review}

Shannon and Weaver (1949) says that communication is a form of human interaction that influence each other, intentionally or unintentionally, that is not limited to the forms of communication using verbal language, but also in terms of facial expressions, painting, art and technology. Communication is a process through someone (communicator) which deliver stimulus (usually in the form of words) that intends to change or form the behavior of others (Hovland, Janis, and Kelley, 1953). Communication is a process that connects one part and another part in life (Ruesch, 1957). Webster's New Collegiate Dictionary (1977) explained that communication is a process of exchanging information between individuals through the system in the form of symbols, signs or behavior. Communication as the interaction is understood as a process of action-reaction, cause and effect, whose direction alternately. Communication is a flow system that connects the performance between parts of the organization that produce a synergy (Рапији, 2001). An effective communication is believed to be an important thing in high quality service and care to prevent the emergence of a complaint or problem.

According to Eggen and Kauchak (2001), a communication skill is when doctors use their advanced knowledge in the techniques of verbal communication, non-verbal and through the communications media effectively to maintain the liveliness in asking, collaboration and interaction with the patients. Communication skill is the skill needed by the doctors in speaking, listening, overcoming verbal communication barriers, and understanding non-verbal communication of the patient and able to constructively solve the conflict (Santrock, 2007). Oral communication includes presentation, understanding character of the audience, listening critically, and body language. Oral communication is the ability to explain and present ideas orally in a language that is clear and easily understood to diverse audiences. Chen (2007) says that the occurrence of medical disputes more often caused by the gap perception between doctors and patients. Effective communication is believed to be important in high-quality health services and care services to prevent complaints or problems.

\section{Patient satisfaction}

Ware, Snyder, and Wright (1976) said that patient satisfaction can be defined as an attitude of consumers that some degree of like or dislike for health services ever experienced. Crosby, et al. (1990): and Kim and Cha (2002) said that patient satisfaction was defined as an experience that is based on an assessment made by the patient about the extent to which their expectation on health care could be realized. Patient satisfaction is a main indicator of a health care facility standard and is a measure of quality service. Low patient satisfaction will affect the number of visits that will affect the profitability of healthcare facility itself, while employee attitudes toward customers will also impact the customer satisfaction where customer needs from time to time will increase continually, so did the demand on healthcare quality given (Atmojo, 2006). Patient satisfaction was measured using the overall rating measure of satisfaction, because it reflects the personal preferences of the patient, expectations of the patient and the reality of treatment received. Patients who are satisfied are very valuable asset because if patients are satisfied they will continue to use the services of their choice, on the other hand, if patients are not satisfied they will tell two times more powerful to others about their bad experience (Wahyuni, et al., 2013). 


\section{Implicit Self-theorist}

Implicit self-theorist (IST) is divided into two parts, namely: incremental theory and entity theory, where an individual who supports incremental theory would assume that his quality is soft and can be enhanced by his own efforts. Otherwise, individual who support the entity theory considers his quality is something that has not changed (Dweck and Legget, 1988). The scientists developed a theory to explain the under investigation phenomenon, layman had come to develop a theory about human characteristics, such as: intelligence, personality, and ability. However, the layman does not develop his theory explicitly as done by the scientists, but it was developed implicitly. Implicit theory (Dweck, 1999) is the specific domains of lay believe against the social reality that can change. This domain extensively covers more internal attributes and within the individual, such as intelligence (Hong, et al., 1999), ability (Butler, 2000) up to attribute that more internal and on the outside of oneself, such as personality of the people (Levy, Stroessner, and Dweck, 1998) and the social environment in which humans live in it (Chiu, et al., 1995; Dweck, Chiu, and Hong, 1995). In general the selfdomain and world domain are conceptually a different matter (Yang and Hong, 2010).

Two types of implicit theory (entity and incremental) become goal orientation antecedent which adopted by individual (Wang, et al., 2010), the individual who support entity belief would believe that satisfaction is something that remains and a character that cannot be controlled, have orientation towards performance, expectations in pursuit the goals as a positive assessment of his/her ability. Whereas for the individual who support the incremental belief, intelligence is something that can be formed (soft) and can be controlled also having orientation toward mastery because it will give a chance for development (Dweck and Legget, 1988). Dweck (1986), Mueller and Dweck (1998), Wang and Biddle (2001) researches show that when given the challenge, individual who support the entity belief shows performance, negative emotion and cognition. Otherwise, individual who support the incremental belief showed an adaptive pattern of motivation such as persistence, positive feeling and solve problems effectively.

\section{Hypothesis Development}

The gap perception between doctor and patient about the disease, patient's excessive expectations of the doctor, the "language" differences, doctor and patient meaning of the message, and or doctor unpreparedness to establish empathic communication to patients and families are often lead to medical disputes (Berry, 2007). In order to therefore avoid the occurrence of medical disputes, the hospital must try to improve their service quality includes the communication skills of doctors. Wahyuni, et al. (2013) said that patients who are satisfied will continue to use the services of their choice, but if patients are not satisfied they will tell two times more powerful to others about their bad experience.

David and Fallowfield (1994); Greenfield, et al. (1985); Ong, et al. (1995) said that patient, who treated by a doctor who performs excellent communication skills, has been proven to improve the health index and recovery level. An effective communication between doctors and patients give an impact on better healthcare, comfort, patient satisfaction, and decrease the risk of malpractice, as well as conflict or dispute between doctors and patients. Trumble, et al. (2006) said that after the doctors got communication skills, the increase of patient satisfaction occurs significantly. From the description above, the authors propose a hypothesis: $\mathrm{H}_{1}$ : A good communication skills of doctors will improve patient satisfaction.

In communication with a patient, a doctor must know the nature of his patient individually, nature of incremental patient looked at intelligence as something that can be formed (soft) and can be controlled, orientation towards mastery and the nature of the entity believes that the satisfaction is something that is fixed and is a nature that cannot be controlled, oriented towards performance, expectations in pursuit of goals is a positive assessment of his ability (Wang, et al., 2010). Implicit self-theory or implicit theory researched by Dweck (1999) is a specific domain that is believed to the social reality that might change. Two important concepts in the implicit theory (Implicit self-theorist), are entity theorist and incremental theorist (Dweck and Bempechat, 1983). Entity theorist in the domain of social world refers to put believe that the static social world and fixed character so it is not possible to change. Meanwhile, incremental theorist in the social world refers to put believe that this world resembles the characteristics of the liquid and soft, because it may be changed or corrected (Yang and Hong, 2010). On the other hand, Trumbel, et al. (2006) said that increases patients are satisfied with their doctor communication skill upon the completion of communication training. Davi and Fallowfield, 1994: Greenfield, et al. 1985; Ong, et al., 1995 said patients who had been handled by a doctor who has good communication skills can improve the health indices and the recovery level. An effective communication between doctors and patients give an impact on better healthcare, comfort, patient satisfaction, and decrease the risk of malpractice, as well as conflict or dispute between doctors and patients.

In this research, implicit self-theorist (IST) is used as a moderating variable between doctor communication skills to improve patient satisfaction. Based on the above, then the proposed hypothesis: $\mathrm{H}_{2 \mathrm{a}}$ : Specific to individual group entity, group of patients who have a high perception of communication skills have a greater satisfaction than the group of patients with a low perception of communication skills. $\mathrm{H}_{2 \mathrm{~b}}$ : Specific to 
groups of patients who have a high perception of communication skills, group of individuals incremental not satisfied more than the individual group entity. $\mathrm{H}_{2 \mathrm{c}}$ : Specific to groups of patients who have a low perception of communication skill, group of individual incremental satisfied more than the individual group entity.

From the description mentioned above, the research model can be described as follows:

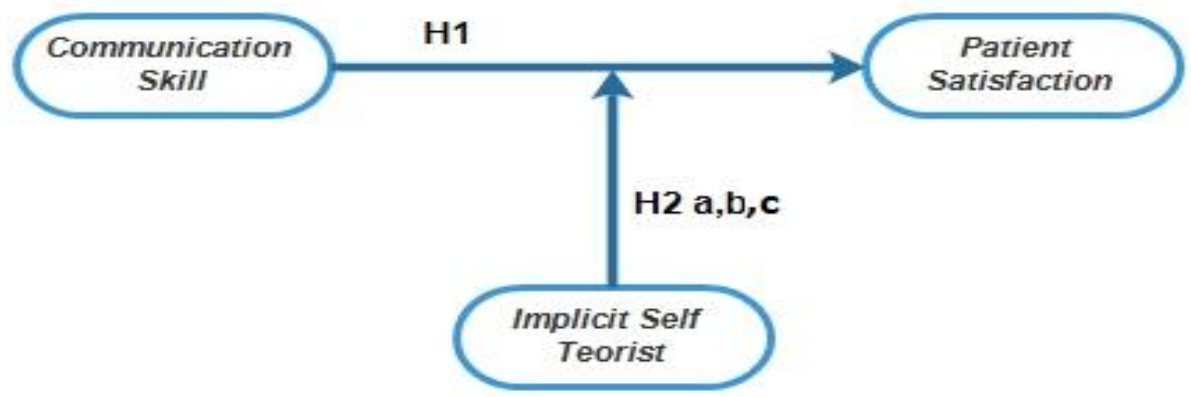

Figure1. Research Model

\section{Research Method}

This research is done on the outpatient in Mayapada Hospital, South Jakarta, Indonesia. Research aspects are communication skills, implicit self-theorist, and patient satisfaction. The research was conducted in December 2016, with a survey method. This research is a descriptive analysis, with a causality model or influence relationships. Data collection is done by distributing questionnaires to outpatient of Mayapada Hospital South Jakarta. Data analysis method in this research used the non-hierarchical statistic; data is processed by using statistical software of GLM (General Linear Model). According to Agung (2006) the sample size used is the total number of average cell multiplied by 30 (the minimum), in which number of the cell is four (Table 1) so that $4 \times 30=120$ respondents, with two variables i.e. communication skills variable which divided into high communication (good) and low communication (bad) and implicit self-theorist which divided into incremental and entity. Classification of communication is done by determining the median split value, a value above the median split classified as high communication (good) and a value below the median split classified as low communication (bad) with classification of implicit self-theorist is done by determining the median split value, a value above the median split classified as incremental and value below the median split classified as entity. Data that has been collected afterward conducted Likert scale measurement on scale of one to seven. Analysis result afterwards is interpreted and the final stage is concluded and given an advice.

Table 1. Between-Subjects Factors Four Cells

\begin{tabular}{|lll|l|}
\hline & & Value Label & $\mathbf{N}$ \\
\hline \multirow{2}{*}{ CSCODE } & 1.00 & Hi & 60 \\
\cline { 2 - 4 } & 2.00 & Low & 60 \\
\hline ISTCODE & 1.00 & Incremental & 60 \\
\cline { 2 - 4 } & 2.00 & Entity & 60 \\
\hline
\end{tabular}

Source: Test result on tools of data analysis

\section{Measurement}

In this study, there is an exogenous variable namely communication skills, an endogenous variable that is satisfaction while implicit self-theorist role as a moderating variable that affecting exogenous and endogenous. Communication skills variable measurement using the indicators of Trumble, et al. (2006) consisting of ten indicators, patient satisfaction variable were adopted from Syah (2014) adapted from Crosby, et al. (1990); Kim and Cha (2002); Lin and Ding (2006) consisting of eight questions, implicit self-theorist variable was adopted from Syah (2014) adapted from Levi, et al. (1998) consisting of four questions, furthermore, the measurement indicator is displayed in the form of a questionnaire, and then tested the validity and reliability.

This study is using confirmatory factor analysis by doing validity test to see the value of Kaiser-MeyerOlkin measure of sampling (KMO) and measures of sampling adequacy (MSA). In this research, the value obtained must be greater than 0,5 which means that the analysis factor is right or appropriate for use, and can be further processed (Malhotra, 2004). Communication skills scales consist of 10 questions and there are 8 valid questions (MSA > 0,5). Questions that are not accepted is CS3 and CS4 questions because it was obtained two 
How Implicit self Theorist Moderate The Influence of Doctors Communication Skill on Patient ..

component matrix when included in the data process so that it cannot be included into this research questionnaire. There are 4 questions of Implicit self-theorist scale which are all valid, patient satisfaction scale are 8 questions which are all valid. Reliability testing with Alpha Cronbach value of $>6$ which means reliable (Anindita and Hasyim, 2009), so it can be said that indicators of communication skills, implicit self-theorist and patient satisfaction are reliable as a data collection tools in the research.

\section{Result Analysis}

\section{Result Analysis And Discussion}

In this research, as can be seen in Table 2 where the test of hypothesis 1 by using statistical F-test on the 'communication skills' line where $\mathrm{F}_{0}=42.473$ (Sig. 0,000), with a degree of freedom of $1 / 116$. It indicates a rejection of $\mathrm{H}_{0}$, so it can be concluded that the data support the submitted hypothesis. This shows that patient satisfaction is influenced by good communication skills of doctors. The better communication skills of doctors, the higher patient satisfaction found in a hospital in South Jakarta, Indonesia.

Table 2. Test of Between-Subject Effects

Dependent Variable: Patient Satisfaction

\begin{tabular}{|l|r|r|r|r|}
\hline \multicolumn{1}{|c|}{ Source } & \multicolumn{1}{c|}{ df } & \multicolumn{1}{c|}{$\begin{array}{c}\text { Mean } \\
\text { Square }\end{array}$} & \multicolumn{1}{c|}{ F } & \multicolumn{1}{c|}{ Sig. } \\
\hline Corrected Model & 3 & 15.907 & 25.888 & .000 \\
\hline Intercept & 1 & .294 & .478 & .491 \\
\hline CSCODE & 1 & 26.098 & 42.473 & .000 \\
\hline CSCODE * ISTCODE & 2 & 4.213 & 6.857 & .002 \\
\hline Error & 116 & .614 & & \\
\hline Total & 120 & & & \\
\hline Corrected Total & 119 & & & \\
\hline
\end{tabular}

Source: Test result on tools of data analysis

Table 3. Parameter Estimate Design A (AB).

Dependent Variable: Patient Satisfaction

\begin{tabular}{|l|c|c|r|r|r|}
\hline Parameter & $\boldsymbol{\beta}$ & \multicolumn{1}{c|}{$\mathrm{B}$} & \multicolumn{1}{c|}{$\begin{array}{c}\text { Std. } \\
\text { Error }\end{array}$} & \multicolumn{1}{c|}{$\mathrm{t}$} & \multicolumn{1}{c|}{ Sig. } \\
\hline Intercept & $\boldsymbol{\beta 0}$ & -.832 & .124 & -6.716 & .000 \\
\hline$[\mathrm{CSCODE}=1]$ & $\boldsymbol{\beta 1}$ & 1.304 & .215 & 6.075 & .000 \\
\hline$[\mathrm{CSCODE}=1] *$ ISTCODE$=1]$ & $\boldsymbol{\beta 2}$ & .151 & .215 & .702 & .484 \\
\hline$[\mathrm{CSCODE}=2] *$ ISTCODE$=1]$ & $\boldsymbol{\beta 3}$ & .781 & .215 & 3.636 & .000 \\
\hline
\end{tabular}

Source: Test result on tools of data analysis

In Table 3, are showed hypothesis 2 testing, value that will be tested is in "implicit self-theorist" group, by comparing the degree of high communication skills and low communication skills with the $\beta$ coefficient. This test is done to see any gap differences in patient satisfaction mean deviation (Y) formed by doctors high $(\mathrm{CS}=1)$ communication skills $(\mathrm{CS})$, and low $(\mathrm{CS}=2)$ both on implicit self-theorist (IST), incremental $($ IST $=1)$ as well as entity (IST $=2$ ) after considering the same linear communication skills $(\mathrm{X})$ effect on patient satisfaction (Y) in all cells. The analysis results support hypothesis $\mathrm{H}_{2 \mathrm{a}}$ is specific to individual entity group, the group of patients who have a high perception of communication skills have a greater satisfaction than the group of patients with a low perception of communication skills $(\beta 1)$, with sig. value $0,000(<0,05)$.

On the test result of hypothesis $2 b$, it was found that the analysis result does not support the hypothesis $\mathrm{H}_{2 b}$ that is specific to a group of patients who have a high perception of communication skills, group of individual incremental no more satisfied than the individual entity group, with sig. $0,484(>0,05)$. On the results of hypothesis $2 \mathrm{c}$, it was found that the analysis results support the hypothesis $\mathrm{H}_{2 \mathrm{C}}$ that is specific to the group of patients with a low perception of communication skills, individual incremental group are more satisfied than the individual entity group $(\beta 3)$, with sig. value $0,000(<0,05)$. 
How Implicit self Theorist Moderate The Influence of Doctors Communication Skill on Patient ..

Table 4. Structural Relationship Test Result

\begin{tabular}{|c|l|c|c|}
\hline Hypothesis & \multicolumn{1}{|c|}{ Hypothesis Statement } & $\begin{array}{c}\text { Sig. } \\
\text { Value }\end{array}$ & Notes \\
\hline $\mathrm{H}_{1}$ & $\begin{array}{l}\text { Doctor communication skills improve patient } \\
\text { satisfaction }\end{array}$ & 0.000 & $\begin{array}{c}\text { Data support the } \\
\text { hypothesis }\end{array}$ \\
\hline $\mathrm{H}_{2 \mathrm{a}}$ & $\begin{array}{l}\text { Specific to individual group entity, group of patients } \\
\text { who have a high perception of communication skills } \\
\text { have a greater satisfaction than the group of patients } \\
\text { with a low perception of communication skills }\end{array}$ & 0.000 & $\begin{array}{c}\text { Data support the } \\
\text { hypothesis }\end{array}$ \\
\hline $\mathrm{H}_{2 \mathrm{~b}}$ & $\begin{array}{l}\text { Specific to groups of patients who have a high } \\
\text { perception of communication skills, group of } \\
\text { individuals incremental is not more satisfied than the } \\
\text { individual group entity }\end{array}$ & 0.484 & $\begin{array}{c}\text { Data does not } \\
\text { support the } \\
\text { hypothesis }\end{array}$ \\
\hline $\mathrm{H}_{2 \mathrm{c}}$ & $\begin{array}{l}\text { Specific to groups of patients who have a low } \\
\text { perception of communication skill, group of } \\
\text { individual incremental is more satisfied than the } \\
\text { individual group entity }\end{array}$ & 0.000 & $\begin{array}{c}\text { Data support the } \\
\text { hypothesis }\end{array}$ \\
\hline
\end{tabular}

\section{Discussion}

Research that previously conducted indicates an inline relationship between the impacts of the good communication skills of the doctors to patient satisfaction in a research conducted in Australia (Trumble, et al., 2006). Thus, better communications skills of the doctors and the improvement of patient satisfaction are expected could bring a good impact on patient's health as well as hospital service conditions.

The test result of Hypothesis 1 , found that analysis result supported hypothesis $\mathrm{H}_{1}$, i.e. a good communication skills of the doctors improve patient satisfaction. The results of this research reinforce previous research conducted by Trumbel, et al. (2006), which said that patient's satisfaction to their doctor's communication skills increased after communication training, which means a better communication skills will create higher patient satisfaction. As well as Davis and Fallowfield (1994); Greenfield, et al. (1985); Ong, et al. (1995) also said that patients who had been treated by a doctor who has good communication skills, had their health indices and recovery level increased. An effective communication between doctors and patients gives an impact on better healthcare, comfort, patient satisfaction, and decrease the risk of malpractice, as well as the disputes between doctors and patients can be avoided.

The test result of Hypothesis $2 \mathrm{a}$, found that analysis results supported the hypothesis $\mathrm{H}_{2 \mathrm{a}}$ i.e. specific to individual group entity, group of patients who have a high perception of communication skills have a greater satisfaction than the group of patients with a low perception of communication skills $(\beta 1)$. The result of this research strengthens previous research conducted by Trumbel, et al. (2006), which said that a better patient satisfaction towards better doctor communication skill, wherein the better doctor communication skill will create higher patient satisfaction and vice versa.

The test result of Hypothesis $2 b$, found that analysis results do not supported the hypothesis $\mathrm{H}_{2 b}$ i.e. specific to groups of patients who have a high perception of communication skills, group of individual incremental is not more satisfied than the individual group entity $(\beta 2)$. This hypothesis does not support the opinion of Wang, et al. (2010) which said that individual who has orientation on mastery is tend to have incremental belief, especially for domains in the hospital service is not proven, it is because individual with entity belief also has the orientation on mastery over their own health. Wherein, the individual entity also has the curiosity over the state of their health from doctor's good (high) communication skills. This hypothesis is also not in line with Shah (2014) research which said that when given the high participation facility, individuals with tendency of incremental would response a better re-rational quality than individuals with entity tendency and vice versa. Thus, specific to domain in hospital services, satisfaction toward perception of high communication skills not only on individual incremental but individual entity also showed satisfaction, as a matter of their own health, good communication skills of doctors is needed by individual incremental and entity.

The test result of Hypothesis $2 \mathrm{c}$, found that analysis result supported the hypothesis $\mathrm{H}_{2 \mathrm{c}}$ i.e. specific to groups of patients who have a low perception of communication skill, group of individual incremental is more satisfied than the individual group entity ( $\beta 3$ ). This hypothesis did not support Davis and Fallowfield (1994); Greenfield, et al. (1985); Ong, et al. (1995) researches which said that patient who had been treated by a doctor who has good communication skills can improve the health indices and recovery level. This hypothesis is also not in line with the research of Syah (2014) that said, in the occasion of individual low participation with a tendency of entity gives a better rational quality respond. In health communication between doctor and patient, poor communication problem is sometimes encountered. This hypothesis indicates that doctor poor communication, a group of individual incremental is more satisfied, this is due to individual incremental is more 
adaptive and resolve problems effectively, so can adapt with a situation where the doctor communication skills is low but remain providing a recovery for such patient. This hypothesis support the research of Dweck (1986), Mueller and Dweck (1998), Wang and Biddle (2001) said that individual who supports incremental belief showed adaptive motivational patterns, such as persistence, positive feelings and solve problems effectively. Doctor poor communication (low) can lead to patient dissatisfaction, but the individual incremental shows positive feelings and more understanding than the individual entity. So that on the domain of healthcare, patients with incremental tendency are more trying to understand the condition of the doctor who has poor communication (low), but still do an effort as a learning to obtain satisfaction on the treatment against him. Whereas entity patient has a contrary view, by show their performance, negative emotions and cognition. Bad communication (poor) from a doctor is regarded by individual entity as inability of doctor in solving health problems that he was experiencing, so it appears unsatisfied feelings, in the form of complaints on doctor performance. Thus, from these hypotheses can be concluded that implicit self-theorist moderate influence doctor communication skills on patient satisfaction

\section{Managerial Implications}

This research discusses the factors that influence patient satisfaction in a hospital in South Jakarta, Indonesia specifically on doctor communication skills that moderated by implicit self-theorist. Managerial implication that can be suggested is on early stages when the patient arrives, the patient data need to be collected at admission department by entering a question about the individual nature, to know that the patient is belongs to incremental or entity category, so that the patient can be directed in accordance with their individual nature to be handled by the right doctor.

The next necessary managerial implications that need to be done by hospital in South Jakarta, Indonesia is to involve doctors onto communication skills training. Although it seems so easy, communicate to master other people requires a special skill. Communication skills training for doctors can be held through internal training and external training. An initial stage in conducting internal training is to compose communication skills training syllabus for doctors. What is meant by training program is to pass on inspiration, advice, and insights related to aspects in communication especially in the hospital which is required for every doctor at his/her work environment. A hospital in South Jakarta, Indonesia also needs to have training budget to regularly send doctors to external communication training, so hopefully, upon the completion of the communication skills training, both internal and external training, the number of outpatient at a hospital in South Jakarta, Indonesia, would increase.

To achieve compliance in communication skills, a Standard Operating Procedures (SOP) needs to be made. Assessments on doctor communication also need to be distinguished from general doctor who has participated and who has never participated in communication training, as well as general doctor who has participated and who has never participated in clinical ability training. Based on SOP created, in order to monitor the compliance of doctor communication skills after participating in training, CCTV monitoring through gesture of the body could be undertaken, however, the supervision via CCTV should have restrictions to consider patient's privacy. Other form of supervision is by sending a 'mysterious patient' periodically to assess the communication skills. To improve doctor compliance, hospitals need to penalize doctors who do not adhere the SOP properly, starting from the reduction of hours of practice, the closure of doctor's clinic and replaced by another doctor, ban the practice in the clinic of doctor concerned, and vice versa to provide rewards to doctors who have patients with the best communication skills within a period of 6 months. It is expected that the training on communications skills would increase patient satisfaction, so that the number of outpatient visits would increase as well.

\section{Conclusion}

Results that can be concluded from this research are: first, doctor communication skills improve patient satisfaction. A good communication skills of a doctors can increase patient satisfaction (first hypothesis is supported). Second, specific to individual group entity, the group of patients who have a high perception of communication skills have a greater satisfaction than the group of patients with a low perception of communication skills (the second hypothesis is supported). For medical world, the individual nature of group entity still expects doctor high communication skills toward the health problems which patient face. Third, specific to group of patients who have a perception of high communication skills, individuals incremental group is not more satisfied than individual entity group (the third hypothesis is not supported), because the domain of hospital services, entity patients concern against doctor good communication is also an important matter, so both incremental and entity patient, together see the health problems which they suffered as a very important matter. Fourth, specific to the group of patients with a perception of low communication skills, individual incremental group is more satisfied than individual entity group (the fourth hypothesis is supported). This is because incremental patient was more adaptive and may resolve problems effectively, so that such patient can adapt to a 
How Implicit self Theorist Moderate The Influence of Doctors Communication Skill on Patient ..

situation where a doctor communication skills is low but doctor is still able to provide recovery on patient. Thus, these hypotheses can conclude that implicit self-theorist moderates influence doctor communication skills on patient satisfaction.

\section{Limitation of Research}

\section{Limitations Of Research And Recommendations}

Limitations of this research can be considered for future researches. This research used a questionnaire as a measuring tool for the purposes of time and energy saving. However, the questionnaire has limitations, such as bias in filling questions. There is a possibility that the respondents did not truthfully answer the questionnaire or just fill out the answer of the questionnaire based on ideal conditions expected and not on the actual and ongoing situation. This can affect the measurement used could not describe the real variables. Moreover, the limited number of samples and variables that influence doctor communication skills on patient satisfaction that moderated implicit self-theorist, as well as the number of analysis has made researcher not to be able to explore more thoroughly on other factors which affect patient satisfaction.

\section{Recommendations for Future Research}

This research scope is still very limited because it only researches the extent of doctor communication skills on patient satisfaction that moderated implicit self-theorist. It is therefore expected that the research development of future researches could add another variable that affect patient satisfaction, such as the service quality variable and others. It is also expected that further researches would study on the object of research of another service company, such as banking company, hotel, notary services and other service companies, in order to obtain more objective and representative result with wider coverage.

\section{References}

[1] Anindita, R., \& Hasyim. (2009). Prinsip-prinsip dasar metode dalam pemasaran. Jakarta: Universitas Esa Unggul.

[2] Agung, I.G.N. (2006). Statistika penerapan model rerata-sel multivariate dan model ekonometri dengan SPSS. Jakarta: Yayasan SAD SATRIA BHAKTI..

[3] Atmojo, T. (2001). Buku ajar ilmu penyakit dalam, Jilid I, Edisi 3. Jakarta: Balai Penerbit FKUI.

[4] Chen, W. (2007). Research into care quality criteria for long-tern care. Jakarta: Direktorat Jenderal Pelayanan Medik.

[5] Chiu, C., Dweck, C.S., Tong, Y.Y., \& Fu, H.Y. (1997). Implicit theories and conceptions of morality. Journal of Personality and Social Psychology.

[6] Crosby, L., Evans, K., \& Cowles, D. (1990). Relationship quality in service selling: an interpersonal influences perspective. Journal of Marketing.

[7] Davis, H., \& Fallowfield, L. (1994). Counselling and communication in healthcare. Chichester: John Wiley.

[8] Dweck, C.S., \& Leggett, E. (1988). A social cognitif approach to motivation and personality. Psychological Review.

[9] \& \& Bempechat, J. (1983). Children's Theories of Intelligence: Consequences for Learning. In S. Paris, G. Olsen, and H. Stevenson (eds.), Learning and Motivation in the Classroom.Mahwah, N.J.: Erlbaum.

[10] Chiu, C., \& Hong, Y. (1995). Implicit theories and their role in judgments and reactions: A world from two perspectives. Psychological Inquiry.

\& Sorich, L. 1999. Mastery-oriented thinking. in C. R. snyder (Ed.), coping: The psychology of what works. New York: Oxford University Press.

[12] Eggen, P., \& Kauchak, D. (2001). Strategies for Teachers: Teaching Content and Thinking Skills.Boston, Massachusetts: Allyn and Bacon

[13] Greenfield, S., Kaplan, S., \& Ware Jr, J.E. (1985) Expanding patient involvement in care. Effects on patient outcomes. Ann Intern Med.

[14] Hong, Y., Chiu, C., \& Dweck, C.S. (1995). Implicit theories of intelligence:Reconsidering the role of confidence in achievement motivation. In M. Kernis (Ed.), Efficacy, agency, and self-esteem . New York: Plenum

[15] Hovland, C.I., Janis, I.L., \& Kelley. (1953). Communication and persuation. New Haven: Yale University Press.

[16] Kim, W.G., \& Cha, Y. (2002). Antecedents and consequences of relationship quality in hotel industry. Hospitality Management.

[17] Levy, S.R., \& Dweck, C.S. (1998). The impact of children's static vs.dynamic conceptions of people on stereotype formation. Manuscript submitted for publication.

[18] Lin, C.P., \& Ding, C.G. (2006) Evaluating the Group Differences in Gender During the Formation of Relationship Quality and Loyalty in ISP Service. Journal of Organizational and End User Computing.

[19] Malhotra, N.K. (2004). Riset pemasaran: Pendekatan terapan. Jakarta: Indeks Kelompok Gramedia.

[20] Mueller, C.M., \& Dweck, C.S. (1998). Intelligence praise can undermine motivation and performance. Journal of Personality and Social Psychology.

[21] Ong, L.M., de Haes, J.C., Hoos, A.M., \& Lammes, F.B. (1995). Doctor-patient communication: A review of the literature. Social Science and Medicine.

[22] Panuju, R. (2001). Perilaku organisasi dan komunikasi suatu pengantar. Jakarta: Gramedia Pustaka Utama.

[23] Ruesch, J. (1957). Principles of human communication. Dialectica.

[24] Santrock, J.W. (2007). Psikologi pendidikan (edisi kedua). (Penerj. Tri Wibowo B.S). Jakarta: Kencana.

[25] Shannon, C.E., \& Warren, W. (1949). A mathematical model of communication. Urbana, IL: University of Illinois Press.

[26] Syah, T.Y.R. (2014). Provider's participation facility as customer loyalty creator, mediated by relationship quality, and moderated by implicit self theorist. University of Indonesia.

[27] Trumble., S.C., O’Brien, M.L., O’Brien, M., \& Hartwing, B. (2006). Communication skill training for doctors increases patient satisfaction. Clinical governance: an international journal. 
[28] Wahyuni, A., Nurachmah, E., \& Herawati, T. (2013). Analisis praktik residensi keperawatan medikal bedah pada pasien gangguan sistem kardiovaskuler dengan pendekatan model adaptasi roy di rumah sakit jantung dan pembuluh darah harapan kita Jakarta. Jurnal Sains.

[29] Wang J.C.K., \& Biddle J.H.S. (2001). Young People's Motivational Profiles in Physical Activity: A cluster Analysis. Journal of Sport \& Exercise Psychology. Human Kinetics Publishers, Inc.

[30] Ware, J.E., Wright, W., Russell, S., \& Mary, K. (1976). Development and validation of scales to measure patient satisfaction with health care services. Vol. 1. Southern Illinois University School of Medicine Office of Health Systems Research.

[31] Yang, Y.J., \& Hong, Y.Y. (2010). Implicit theories of the world and implicit theories of the self as moderators of self-stereotyping. Social Cognition, 28(2), 251-261. 